\title{
POETIC APPROACH IN THE STUDY OF A DRAMA SCRIPT: ANALYZING THE DISAPPOINTMENTS FACED BY WILLY LOMAN IN ARTHUR MILLER'S DEATH OF A SALESMAN IN TEACHING ENGLISH AS A FOREIGN LANGUAGE CONTEXT
}

\author{
Astri Hapsari \\ Melbourne University
}

\begin{abstract}
This article describes and explains how literary competence for the teaching of literature in English as a foreign language (EFL) context can be achieved by taking Culler's (1997) poetics in the study of literature as a theoretical framework. The implementation of this approach is discussed by using one of the famous drama scripts in American literature: Death of Salesman written by Arthur Miller. Following Culler's poetics approach, the analysis focuses on one of the themes found in the drama script: the disappointments faced by Willy Loman (the main character) which make up most of the plot with a dramatic ending: Willy's decision to suicide. This article aims to encourage EFL teachers who use literature as the object of study to take Culler's side by using poetics as the starting point in a literature study in order to improve the learners' literary competence.
\end{abstract}

Key words: literary competence, poetic approach, teaching literature in EFL context, the study of a drama script, Death of a Salesman

\section{INTRODUCTION}

Literature is important product of a literate society because it is a written text which describes what people do and how people live in a society. Guerin (2005) mention that even though literature has basic stance as art, it must be acknowledged that "art does not exist in vacuum" (p. 17) and it is intended to deliver some ideas that are relevant to the real human experience in history. As a 
result, doing literary study enriches our knowledge about human existence. Therefore, the use of literature in English as a foreign language (EFL) context is important because literary works enable the students to learn about different world views, enrich the students' perspective and indirectly teach them how to appreciate the differences in the real society (Hapsari, 2011). In addition, in EFL context where students rarely use English in their daily conversation, literature is essential teaching source because it provides examples of the language use in a context, such as in reading a drama script, the students know how certain expressions are used in a conversation (Hapsari, 2011).

\section{POETICAPPROACH IN THE STUDY OF LITERATURE}

Culler $(2000,2002)$ conceptualizes the notion of literary competence which refers to the ability to have an understanding of the meaning beyond what it is literary written in the text which requires the reader of a literary work to comprehend the operations of literary discourse, its implicit semiotic signs and culture. Culler (2000) also highlights the difference between what is called poetics and hermeneutics in the study of literature. Poetics starts with the meaning of literary work while hermeneutics starts with form. He further explains that "the modern tradition of criticism" has submerged in hermeneutics or combined poetics and hermeneutics (Culler, 2000, p. 61). Moreover, he argues that poetics should be taken as "the first track" in linguistic model of literary study (Culler, 2000, p.61). He further argues that it is poetics, which focuses on the conventions that make possible literary structure and meaning. As a consequence, literary competence involves the readers' ability to identify "literary genres, recognize plots, create characters out of the scattered details provided in text, identify themes in literary works, and pursue the kind of symbolic interpretation that allows us to gauge the significance of poems and stories".

Following Culler's poetic approach in the study of literature, this essay aims to describe and explain the implementation of this approach in analyzing one of the themes found in Arthur Miller's Death of a Salesman: the disappointments of Willy Loman (the main character in the drama script). 


\section{WILLY LOMAN'S DISAPPOINTMENTS WHICH LEAD HIM TO SUICIDE: ONE OF THE MAJOR THEMES IN MILLER'S DEATH OF A SALESMAN}

Death of Salesman is a play written by Arthur Miller which focuses on a family as the most important element. This two-act play contains certain private conversations which happen in two days and lead to Willy Loman's decision to suicide. With such decision, there must be some failures in life that Willy has done which makes him feel disappointed. Thus, the disappointments faced by Willy Loman are one of the major themes in Arthur's Miller Death of a Salesman and the following paragraphs will discuss the disappointments which lead Willy Loman to suicide.

Willy Loman is a past sixty years of age salesman. In Act I, it is revealed that Willy has so many things to complain. He does not feel satisfied with his job (p. 9-10), his thirty-four-year-old son named Biff who has not got a stable job and almost always disagrees with him (p. 10), his environment (p. 11), and even himself (p. 21).This complains infers that Willy is mentally unbalance.

There are also several flash-back plots which describe Willy's thought about the past and the way he wishes life must be. From Willy's flash back thought it is revealed that in the past Willy had a good relationship with both Biff and Happy (p. 17-21). This flash back plot also reveals that Willy taught his sons that a person is well-liked and succeeds because of his appearance, not his education.

"Willy : That's just what I mean. Bernard can get the best marks in school,..., but when he gets out in the business world, you are going to be five times ahead of him. That's why I thank Almighty God you're both built like Adonises. Because the man who makes an appearance in the business world... is the man who gets ahead..."(p.20)

From this statement, it is revealed that Willy does not pay attention to his sons' education. He thinks that good looking is enough to succeed.

But then, in Act II, Willy starts to realize that what he has taught to his son is wrong when he meets Bernard, the son of his neighbor, Charley, and his sons' friend, who grows up as a mature adult who has become a successful lawyer (p. 5152). 
Willy: How-how did you? Why didn't he ever catch on?

Bernard: I wouldn't know that, Willy.

Willy : You were his friend, his boyhood friend. There's something I don't understand about it...nothing good ever happened to him.

Bernard: He never trained himself for anything (p. 51)

From Bernard's statement, it is inferred that Biff has never got a stable job because he is lack of educational background. Biff didn't graduate from high school because he flunked in math exam and didn't enroll in summer school after he'd gone to New England to meet his father.

Furthermore, the flash back thought also reveals that in the past Willy has an affair with a woman (p. 22-23) but Linda does not know about it at all. Biff, who found out that Willy had an affair, felt very disappointment (p. 65-67). For Biff, his mom, Linda, is an obedient and faithful wife so that she deserves to have a full respect from his father. In addition, Biff could not accept the reality that his father who he admires a lot could do such a nasty thing. That is why when he found out that his father was a dishonest person who betrayed his marriage; he was so angry and frustrated that he started neglecting his own life. Biff becomes a loser who failed to graduate high school, stole things, spent some time in prison, has never had permanent job, and constantly argued with Willy. When Willy realizes that Biff's failure in life is part of his mistake, he feels guilty. (p. 74).

Bernard : He wasn't beaten by it all. But then, Willy, he disappeared from the block for almost a month. And I got the idea that he'd gone up to New England to see you. Did he have a talk with you then?

Willy stares in silence

Bernard: Willy?

Willy (with a strong edge of resentment in his voice) : Yeah, he came to Boston. What about it?

Bernard: Well, just that when he came back I'll never forget this, it always mystifies me... Willy, y'know? And he came back after that month and took his sneakers- remember those sneakers with "University of Virginia" printed on them?...And he took them down in cellar, and burned them up in the furnace... What happened in Boston, Willy?

Willy looks at him as at intruder... 
Bernard: Well, don't get sore

Willy (angrily) : What are you trying to do, blame it on me? If a boy lays down is that my fault?

From this conversation, it can be inferred that Willy starts to feel he has failed as a father. He finally realizes that his affair has made his son become a loser.

Other disappointment faced by Willy Loman is that he can't give financial security to his wife, Linda. Willy loves Linda very much because she is such an obedient, faithful, and patient wife. He does not want his wife worries about him (p. 11,22).And somehow, Willy feels so guilty about his affair (p. 23, 41) that he wants to keep working to give financial security to Linda. But the era has changed. His boss' son, Howard, retires Willy (p. 46). When Charley, his neighbor, offers him a job, Willy refuses it because he feels a kind of competition and jealousy to Charley. But Willy keeps borrowing money from Charley (p.53-54).

Furthermore, Willy is disappointment because he thinks he has lost in his competition with Charley. Charley's son, Bernard, is successful in running his career while his son, Biff, is jobless. Charley is stable financially while he has to keep borrowing money to Charley. Willy feels that all his hard work for years is meaningless

Willy (moving to the right) : Funny, y' know? After all the highways, and the trains, and the appointments, and the years, you end up worth more dead than alive (p. 54).

From Willy' statements it can be inferred that Willy starts to feel pathetic about his condition and thinks about death. This statement implicitly gives a sign that Willy plan to suicide.

Other disappointment faced by Willy Loman is that his sons neglect him at the restaurant and prefer to chase for a date. At the restaurant, Happy is more concern about the opportunity to date Miss Forsythe than about his father's feeling. At that time, Willy has a flash-back thought about the time when Biff went to see him at Boston and found out he had an affair with a woman. Willy somehow compares his condition of being neglected by his sons now (p. 60-65) as the condition in Boston (p. 65-66) which he felt that he had neglected his family for his own pleasure. It is also inferred that Happy inherits Willy's nature to have affair with women. Happy never feels satisfied with one woman (It also mentions in Happy's statement in page 15) and neglects his family (his father, while at the 
restaurant), just like Willy who does not feel satisfied with his loyal and obedient wife, Linda and neglect his sons (Biff, Happy).

In conclusion, Willy Loman faces several disappointments. First, he feels he has failed as a husband to be a loyal partner and to give financial security to his wife. Second, he feels he has failed as a father to be a good example for his sons (Biff and Happy) and to guide him to be successful men. Third, he feels he has failed in his competition with his friend, Charley. These disappointments make Willy Loman feel pathetic and decide to end his life in a suicide.

\section{FURTHER DISCUSSION: HOW POETIC APPROACH IN STUDYING THE THEME IMPROVES THE STUDENTS' LITERARY COMPETENCE}

From the previous analysis of one of the major themes in Miller's Death of a Salesman, that is, Willy Loman's disappointments which lead him to suicide, it is clear that the discussion of a theme can lead to a more profound comprehension about the literary text. The analysis of Willy Loman's disappointments can scaffold the students to be more conscientious with the meaning revealed from the dialogues between the characters in the drama script. For example, in the following script's quotation (p.74):

Bernard : He wasn't beaten by it all. But then, Willy, he disappeared from the block for almost a month. And I got the idea that he'd gone up to New England to see you. Did he have a talk with you then?

Willy stares in silence

Bernard: Willy?

Willy (with a strong edge of resentment in his voice) : Yeah, he came to Boston. What about it?

Bernard : Well, just that when he came back I'll never forget this, it always mystifies me... Willy, y'know? And he came back after that month and took his sneakers- remember those sneakers with "University of Virginia" printed on them?...And he took them down in cellar, and burned them up in the furnace... What happened in Boston, Willy?

Willy looks at him as at intruder...

Bernard: Well, don't get sore 
Willy (angrily) : What are you trying to do, blame it on me? If a boy lays down is that my fault?

In order to understand how the guilty feeling simultaneously comes to Willy's mind and guide his decision to suicide, the students have to study the plot, the sequence of the story, the cumulative flash back events that motivates Willy's utterance to Bernard,

Willy (angrily) : "What are you trying to do, blame it on me? If a boy lays down. is that my fault?

These conscientious steps are directed from the discussion of the disappointments faced by Willy Loman. Without careful analysis of the events that lead towards the conversation between Bernard and Willy, the students will not be able to reveal the meaning in the conversation. Therefore, in order to achieve the degree of this literary competence, a careful structural analysis of utterance is a must. Misson et al. (1994) refers Culler's literary competence to "structuralist framework" which the readers develop since it involves a thorough analysis of the intrinsic elements in the literary work. Taking Culler's $(2000,2002)$ stance, poetic approach is indeed a better track to begin a study of literature than hermeneutics approach. However, it does not mean that hermeneutics approach which involves extrinsic elements of the literary work is not valid to guide the study of literature. The point is that a poetic approach which involves a thorough analysis of the intrinsic elements should be the starting point in order to make the students be more focus on and develop their appreciation at the literary work as the object of study. Even though literature has basic stance as art, it must be acknowledged that "art does not exist in vacuum" (Guerin, 2005), extrinsic elements should be used to scaffold learning only if the students have already had enough time to study the structure of the literary work as the object of study first.

In conclusion, taking stance of Culler's $(2000,2002)$ and Misson's et. al (1994) arguments on how important the study of the intrinsic elements in the study of literature are I shall argue that poetic approach should precede hermeneutics approach in the study of literature. While not taking the conventional formalist view that the literary text itself is self-sufficient, I believe that teaching literature in EFL context should motivate the students to appreciate the literary work first before developing their critical analysis from the extrinsic elements which involve in the making of the literary work. 


\section{References}

Culler, J. (2000). Literary theory : a very short introduction. Oxford: Oxford University Press.

Culler, J. (2002). Chapter 6: LITERARY COMPETENCE. Structuralist Poetics, 131-152. Retrieved from EBSCOhost.

Guerin, W.L. (2005). A handbook of critical approaches to literature (fifth edition). Oxford: Oxford University Press.

Hapsari, A. (2011). Literary competence for the teaching of literature in second language educational context. Journal of English and Education. Yogyakarta: Universitas Islam Indonesia

Miller, A. (2000). Death of a Salesman. London: Penguin Classics

Misson, R., \& Victorian Association for the Teaching of English. (1994). A brief introduction to literary theory. [Carlton, Vic.]: Victorian Association for the Teaching of English.

Misson, R., \& Morgan, W. (2006). Critical literacy and the aesthetic : transforming the English classroom. Urbana, Ill.: National Council of Teachers of English.

Roberts, E. (1999). Writing about Literature. New Jersey: Prentice-Hall, Inc. . 